\title{
溶接再現熱サイクル材における動的破壊靯性值 $\boldsymbol{K}(\boldsymbol{T}, \boldsymbol{K})$ の挙動*
}

\author{
菊田米男** 落合真一郎** 大杉卓生 $* * *$ 平山朝朗****
}

\author{
Dynamic Fracture Toughness $K(T, \dot{K})$ Behaviors \\ at Simulated Weld of SM-50 Steel*
}

by Yoneo Kikuta**, Shin-Ichiro Ochiai**, Akio Ohsugi*** and Asao Hirayama****

It is known that fracture toughness value changes, within the same material, depending on the ambient temperature and loading rate used for testing. For some material, fracture toughness value obtained at rapid loading rate is considerably lower than the one by static case. Thus the former value has more critical meaning on fracture mechanics standpoint.

We have succeeded for the first time to measure dynamic fracture toughness $K(T, \dot{K})$ behaviours by using calibrated piezo-electric transducer for load detection. The signal is amplified by charge amplifier, and is recorded by digital memory. SM 50 steel was chosen for the present investigation because of its expectedly strong loading rate dependence of fracture toughness value. For dynamic testing, extraneous signals due to inertial loading and specimen vibrations were circumvented by lowering initial tup velocity.

$K(T, \dot{K})$ was measured at the temperature range between $-196^{\circ} \mathrm{C}$ and room temperature. Strong loading rate dependence was found for simulated H.A.Z. and base metal. On the other hand, simulated weld-bond, which has poor toughness at slow bend test, has small dependence of fracture toughness value on loading rate. The difference in the dependences is very clear at higher temperature range, and they both become less sensitive to loading rate as temperature decreases toward $-196^{\circ} \mathrm{C}$ where the loading rate dependence essentially disappears. Furthermore, temperature dependence of fracture toughness value was found to be large for simulated H.A.Z. and base metal while the dependence is much less for simulated weld-bond.

\section{1. 緒言}

材料の破壊靱性は温度, 荷重速度, 板厚などに依存す るととが知られており, 高荷重速度においては破壊靱性 值が低下することが Rolfe $\mathrm{e}^{1)}$, Bedesem ${ }^{2}$ らによって指 摘されている. とのととは原子炉圧力容器, 各種タン クパイプラインなどのごとく衝撃荷重の負荷される可 能性のある構造物倸おいては，安全設計上非常に重要な 意味を持つと考えられる. 以上のととを反映して原子炣 圧力容器などを対象とした ASME boiler and pressure vessel code, section III, nuclear vessels, appendix G 亿括いては動的あるいはき裂伝播阻止の破壊歇性が実際 に採用されている.また Esso 社 ${ }^{2}$ の基準においては圧 力容器類に対して動的な破壊茄性が採用される゙へきであ るとしているままた ASTM においても動的破壊勒性計

\footnotetext{
*原稿受付 昭和51年10月25日(昭和51年度春孚全国大会にて発表)

**正 員 大阪大学工学部 Member, Faculty of Eng., Osaka University

***正員 東洋速船機 Member, Toyo Carrier Machine Co., L.td.

*****学生員大阪大学工学部 Stueent Member, Faculty of Eng., Osaka University
}

測法として比較的簡便な計装化シャルピ一衝撃試験法の 測定方法や，測定上の問題点などを記した ASTM, STP $563(1974)^{3)}$ が刊行されている. このように動的荷重に おける破壊鞄性測定法の研究が多く行なわれるようにな ってきたが，簡便かつ精度の高い方法というすのはいま だ確立されていないようである.とくに溶接部における 動的破壊鞄性についてなされた研觉は数少い.

こういった現状において著者らは広く用いられる檴造 用鋼としての SM50 材を用いて 2 種類の入熱に対して 溶接再現熱サイクルを行ない，ボンド部， HAZ 部を想 定したシャルピ一試片を用いて滾接部の動的破罗勒性の 研究を行なったままた高温域での平面ひずみ破壊䩓性を 評価する一つのパラメータとして Equivalent Energy 法出に上る破壊歎性值 $K^{*}$ を導入した。 また一般に破壊 鞄性は温度之荷重速度の関数であるので，てれを $K$ $(T, \dot{K})$ と表現する方法をとった．测定方法としては高 速現像デー夕処理機と水晶の荷重センサー, チャージア ンプの組合わせによる精度の高い計装化シャルピー試験 機を用いて動的三点曲げ武験を行ない動的破壊鞄性を求 めた．またインストロン型試験機によって静的 3 点曲げ 
栻験をむ行ない，静的破壊敬性をる求めて，溶接部破壊 欨性の荷重速度依存性亡温度低存性を明らかにした。

\section{2. 実 験 方 法}

\section{1 試験片}

供試鋼材は板厚. $25 \mathrm{~mm}$ の SM 50 材であり Table 1 飞その化学組成を示す. 試片は, 素材並びに溶接再現熱 サイクルを行なったすのより切り出した. シャルピー試 片の切り出し方, 試片形状, 寸法はFig. 1 亿示寸通り であり，その長手方向は压延方向之一致させてある. 溶 接再現熱サイクル試片としてあらかじめ $12 \times 12 \times 55 \mathrm{~mm}$ の直方体を切り出したすのに熱サイクルを与え，その後 怔試を版り出した．溶接再現熱サイクルとしては高周 波誘導加熱之，それに続く冷却を行なった．最高加熱温 度は $1050^{\circ} \mathrm{C}, 1450^{\circ} \mathrm{C}$ の 2 種とし冷却方法は自然放置 の空冷亡オイルバスによる油朎の 2 種をとり，素材と合 わせて計 5 種の試片を作った、Table 2 に各試片の冷却 速度, 最高加熱温度, ビッカース硬度, 。 $T_{r S}$ （持ち上げ 角 $120^{\circ}$ ), 入熱, 再現溶接部, 組織を示す。試片 $\mathrm{B}, \mathrm{C}$ は サブマージアーク溶接の入警 Joule $/ \mathrm{cm}$ の場合のそれ ぞれ $\mathrm{HAZ}$ およびボンド相当試片であり, 試片 D， Eは 入熱2.5万 Joule/cm の場合のそれぞれ $\mathrm{HAZ}$ およびボ ンド相当試片である。また陚片Aは素材である、試片 A， B，Dの組織はいづれむフェライトーパーライトで あり，試片Cは結晶粒の粗大化したフェライトーベイナ イト混合組織が見られ，試片Eはやはり結晶粒の粗大化 したフェライトーベイナイトーマルテンサイト混合組織で ある。

本実験では全試片に疲労クラックを $2 \mathrm{~mm}$ 程度入れ た. その原理は 3 点曲げによる繰り返し荷重の目加であ る(使用機：Dynatup プリ・クラカー)，クラックを入れ る際の最大応力拡大係数 $K_{f}$ は $40 \sim 90 \mathrm{~kg} / \mathrm{mm}^{-3 / 2}$ の範 咽であり，後に求めた破塄蚤性值の50\%未満であった。

Table 1 Chemical composition (SM50 Steel) Weight \%

\begin{tabular}{c|c|c|c|c|c|c|c|c}
\hline \hline $\mathrm{C}$ & $\mathrm{Si}$ & $\mathrm{Mn}$ & $\mathrm{P}$ & $\mathrm{S}$ & $\mathrm{Cu}$ & $\mathrm{Ni}$ & $\mathrm{CI}$ & $\mathrm{Mo}$ \\
\hline 0.18 & $\mathbf{0 . 2 4}$ & $\mathbf{1 . 1 0}$ & 0.012 & 0.018 & 0.02 & 0.02 & 0.02 & 0.01 \\
\hline
\end{tabular}

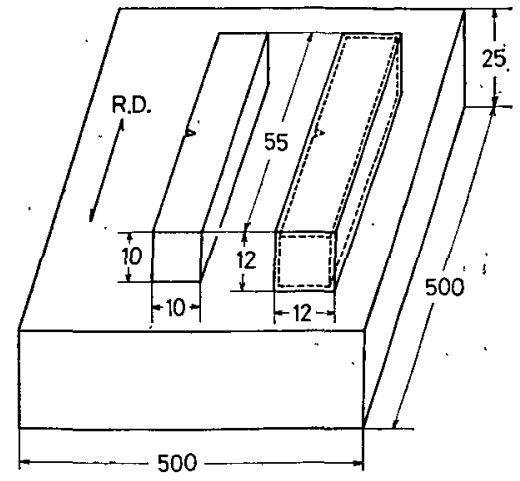

Fig. 1 Specimen geometry in $25 \mathrm{~mm}$ thick SM 50 steel plate

\section{2 静的 3 点曲げ試験}

インストロン型試験機の Load Cell に連結した銑拚 にシャルピー試験機のアンビル部を装置し，そてに試片 を置き先端半径 $1 \mathrm{~mm}$ のタップを一定のクロスンヘッド スピード $5 \mathrm{~mm} / \mathrm{min}$ で降下させ荷重負荷を行ない試験 片を破壊させてレコーダーに荷重一時間曲線を描かせ た. 3 点曲げの治具の支点は次項に述べる動的 3 点阳げ 之同じ位置になるようにした，試験温度は下限を液体窒 素温度，上限を室温としその間を 6 段階にとった。

\section{3 動的 3 点曲げ試験}

実験装置のブロックダイヤグラムを Fig. 2 亿示す. 支点となるシャルピー試験機アンビル部の一方に水晶の 王電効果を利用した荷重センサーを用いて動的 3 点曲げ を行なったセンサーにより，荷重を電気的信号に変换 し、チャージアンプで増幅した後に高速現象デー夕処理 機（ディジタルメモリー）に記憶させる．その後データ をペンレコーダーに再生記録させて荷重一時間曲線を得

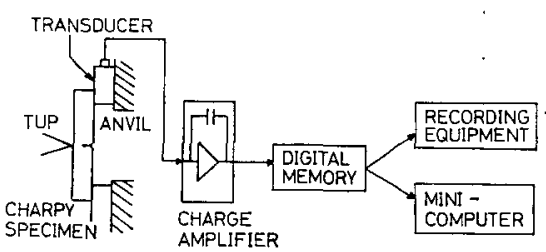

Fig. 2 Block diagram of present instrumentedCharpy testing

Table 2 Specimen Identification

\begin{tabular}{c|c|c|c|c|c|c|c|c}
\hline Specimen & $\begin{array}{c}800^{\circ} 500^{\circ} \mathrm{C} \\
\text { Cooling time }\end{array}$ & Peak temp. & $H_{v}$ & ${ }_{v} T_{r S}$ & Heat input & Simulation & Structure \\
\hline A & - & - & 166 & $-22^{\circ} \mathrm{C}$ & - & Base metal & Ferrite-pearlite \\
B & $200 \mathrm{sec}$ & $1050^{\circ} \mathrm{C}$ & 168 & $-25^{\circ} \mathrm{C}$ & $130 \mathrm{~kJ} / \mathrm{cm}$ & $\mathrm{HAZ}$ & Ferrite-pearlite \\
$\mathrm{C}$ & $200 \mathrm{sec}$ & $1450^{\circ} \mathrm{C}$ & 222 & $100^{\circ} \mathrm{C}$ & $130 \mathrm{~kJ} / \mathrm{cm}$ & Bond & Ferrite-bainite \\
$\mathrm{D}$ & $18 \mathrm{sec}$ & $1050^{\circ} \mathrm{C}$ & 196 & $-30^{\circ} \mathrm{C}$ & $25 \mathrm{~kJ} / \mathrm{cm}$ & $\mathrm{HAZ}$ & Ferrite-pearlite $^{\circ}$ \\
$\mathrm{E}$ & $18 \mathrm{sec}$ & $1450^{\circ} \mathrm{C}$ & 251 & $78^{\circ} \mathrm{C}$ & $25 \mathrm{~kJ} / \mathrm{cm}$ & Bond & Ferrite-bainite. \\
\hline
\end{tabular}


た. ディジタルメモリーは1024のデータを 8 ビットで書 き込み，読み出しを行なう，書き込み，変み出しの時間 間隔は独立して設定することができ，その時間間隔は $100 \mathrm{nsec} / 1 \mathrm{sec}$ の箐囲で任意に選定することができる. また入力信号によって，トリガーをかけ delay stopを 適当に設定する云によって，トリガーのかかる以前の信 号も読み出す機能を持っている. 低温域における試験は 所定温度に掵却保持した試片を 5 秒以内に試験機に据元 つけ，ハンマーを振り落して破断させた。試験温度は下 限を液体窒素温度, 上限を室温として衍 7 段階とった。

\section{3. 実 験 結 果}

\section{1 破壊梯式と破壊鞄性值の算出法}

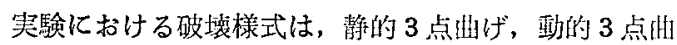
げ，ともに大別して3つのタイプに分かれた. タイプI は遙移温度より低温域で見られたものであり，全面降伏 せずに腕性破壤し，クラックは急速伝播する.タイプII は䢰移領域近くにおいて見られたもので, 荷重が負荷さ れると試片はまず全面降伏を起こし，その後に破垻が発 生しクラックは急速伝播する.タイプ而は室温付近で見 られたものであり，試片は完全延性破壊を起こす．

3つのタイプに対して破壊鞄性值を算出するにあたり タイプIに対しては従来通り破壊荷重 $P_{\max }$ を式 (1) の $P_{\max }$ に代入して破塤跑性值 $K(T, \dot{K})$ を求めた。

$$
\begin{aligned}
& K(T, \dot{K})=6 Y M / B W^{2} \times a^{1 / 2} \\
& Y=1.93-3.07(a / W)+14.53(a / W)^{2}-25.11(a / W)^{3} \\
& +25.8(a / W)^{4} \\
& M=P_{\max } L / 4 \\
& B \quad \text { : 試体片宋 } \\
& W \text { : 試験片厚さ } \\
& a \quad: \text { トタルクラック長 } \\
& M \quad \text { : 破壊発生時の曲げモーメント } \\
& P_{\text {max }} \text { : 最高荷重 } \\
& L \quad \text { : スパン長 }
\end{aligned}
$$

ここで $\dot{K}$ は破壊発発生時の $K$ 值を, 荷重負荷時点加ら $P_{\text {max }}$ に到達するまでの時間で除したものであり，荷重 速度のパラメータ亡なる. 次にタイプ II, タイプIIIに対 しては後述の Equivalent Energy 法を導入し破壊㡕性 を求めた。遙移温度以上の高温域に括いては $K_{I_{c}}$ 值を 得るには大型試験が必要であるが，Witt惊高荷重 に達する前に全面降伏するような破塤の場合の破壊鞄性 值計算において Equivalent Energy 法を用いると, 計 装化シャルピー試験法によって得ら机る破壊靶性值が $K_{I d}$ となり得ることを示した. Fig. 3 において荷重が 最大になるまでに荷重一変位図が囲む面積は破㙍発生に 要するエネルギーに対応すると考えられるので, 最大荷

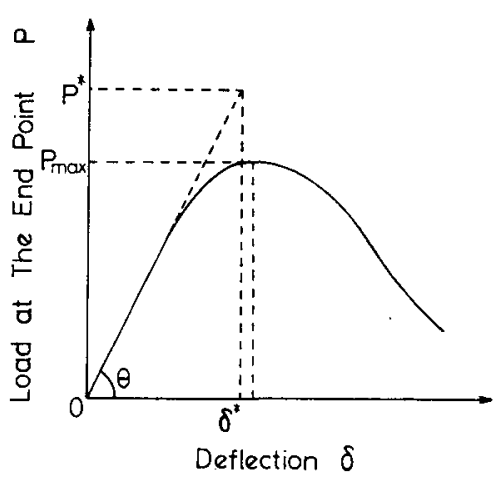

Fig. 3 Equivalent Energy method for the determination of fracture toughness value

重 $P_{\max }$ になるまでに要したエネルギー $E_{1}$ を求める。 次に立ち上がりの角度 $\theta$ の直線を延長し，その直線を 斜辺とした $E_{1}$ 亿等しいエネルギーを持つ直角三解形を 作り，そのとき定まる荷重 $P^{*}$ を相当最大荷重之呼ぶ. これを式(1)の $P_{\max }$ に代入して破燷勤性パラメータ を求め $K^{*}(T, \dot{K})$ 之表記する. 全面降伏後破壊発生し た埸合には，乙の $K^{*}(T, \dot{K})$ を破㑩歌性值とした。

\section{2 試験片の荷重一変位曲線とコンプライアンス の決定}

Equivalent Energy 法を用いる際に, 相当最大荷重 $P^{*}$ については式 $(2)$ が成立する，よって荷重一变位図 の面樍之試片のコンプライアンスを知る必要がある.

$$
\begin{aligned}
P^{*}=\sqrt{2 A \tan \theta}=\sqrt{2 A / \lambda_{s}} \\
A: \text { 荷重一変位図の面筫 } \\
\lambda_{s}: \text { 試片コンプライアンス }
\end{aligned}
$$

静的 3 点曲げ試験で記録計に兒われた荷重一時間曲線 は,クロスヘッドスピードを $5 \mathrm{~mm} / \mathrm{min} の$ 定速で試験 しているととより, 荷重一变位曲線に採算できる.しか しこの変位には試験機（とくに鉄枠）の変位が含まれて いるのでこれを別に求めてその変位成分だけシフトさ せ，試験片自体の荷重一変位曲線を得た。

上述の方法で種々のき裂長を持つ個々の試片に対して 荷重一变位曲線を求め, その立ち上がりの勾配から得た コンプライアンスとクラック長との対応を最小 2 乗法に て求めたものが式( 3 )である. この式( 3 )は試片コンプ

$$
E \lambda_{s} \beta=1162(a / W)^{2}-684.3(a / W)+128 \cdots
$$

ライアンスを決める式として静的，動的試験の両方飞拯 用した. ただしての式はデータ分布より $a / W \leqq 0.45 の$ 筑围においてのみ信頼性が高い.

動的 3 点曲げ試験の場合は，まずタップ速度が初速度

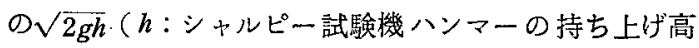
さ）で一定と仮定し，記録計に現れた荷重一時間曲線か ら荷重一変位曲線への変換を行なう.この変位成分には 
試片の変位之試験機の变位が含まれ,コンプライアンス については式(4)が成立する．このうち $\lambda_{s}$ は荷重速度

$$
\lambda_{t}=\lambda_{s}+\lambda_{m}
$$

$\lambda_{t}$ : 記録計から直接得られるコンプライアンス

$\lambda_{m}:$ 試験機のコンプライアンス

に依存しない上仮定し，静的試験による式(3)より決定 した，また $\lambda_{m}$ は，完全な脆性破壊を起てした数点の データから $\lambda_{t}$ と $\lambda_{s}$ を知るととにより式 (4)上り求 め, これが温度変化関係なく一定であると仮定した上 で $\lambda_{m}=2.86 \times 10^{-4} \mathrm{~mm} / \mathrm{kg}$ を用いた. Fig. 4 の曲線 $c_{1}$ は試験機の变位を考虑しない荷重一恋位曲線であり, 曲 線 $c_{2}$ は試験片自体の荷重一変位曲楾である. こてで, それぞれの曲線が囲む面積 $A, A_{s}$ との間には $A_{s}=\lambda_{s} /$ $\lambda_{t} \times A$ の閶係が成立する. 以上の方法で Equivalent Energy 法泟必要な試片のコンプライアンスと破塄発生 までのエネルギーを知り $K^{*}(T, \dot{K})$ を算出した.

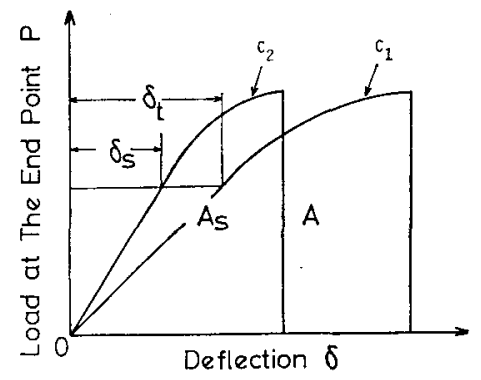

Fig. 4 True load-deflection curve and apparent load-deflection curve which includes machine compliance part

\section{3 計装化シャルピー試験におけるハンマー持ち 上げ角の決定}

動的 3 点曲げ試験において，荷重一時間曲線に現われ る䧴音信号の要素としては, 弾性波と inertial load が 考えられる3).

弹性波は衝整荷重により試片が急速に振動する現象で 古る。乙のとき弾性波の振幅は衝笑速度に依存し, 減衰 時間は衛突速度に依存しない, 式( 5 )は Ireland $\left.{ }^{5}\right)$ の導

$$
\begin{gathered}
t=1.68\left(L / C_{0}\right)(W / L)^{1 / 2}\left(E \lambda_{s} B\right)^{1 / 2} \\
t: \text { 弾性波の周期 } \\
C_{0}: \text { 試片中の音速 }
\end{gathered}
$$

いたものであり，弾性波の周期は試片の材料之形状のみ に倰存する．また Ireland に上れば，式（6)のごとく

$$
t_{f}>3 t
$$

$t_{f}:$ 最高荷重到達時間

最高荷重到達時間が弾性波の周期の 3 倍以上であれば, 十分減衰して弾性波による破壊荷重の測定誤差は無視さ
れ得るとしている. このととより, 試験機ハンマーの持 ち上代角 $\alpha$ 小さくして荷重速度を小さくすると， $t_{f}$ が大きくなるので弾性波の影響は整減される.

次に inertial load 飞ついて, その発生原理を Fig. 5 に示す, 静止している試片にタップが速度 $v_{0}$ で衝突す ると試片速度は零からほぼ $v_{0}$ の值まで急上昇するた め，タップにはその変化に対応する慣性力がかかるこ とになる。とれが inertial load であり，筆者らのよう に，アンビル部における荷重を测定する際にも同様のこ とがいえる．また inertial loadの大きさはタップの街 撃速度 $v_{0}$ にほぼ比例する ${ }^{3}$. Fig. 6 は inertial load に及ぼす持ち上げ角 $\alpha$ の効果を示したものであり， $\alpha$ の 小さい(b)の場合の方が inertial load の影響が小さいと とが判る.

以上述べたように弾性波 inertial load の両面から見 て，より正確な破壊荷重の測定を行なうためには $\alpha$ を小 さくするのが適切なようである，そこで本実験では，破 壊の起とり得る笧囲で， $\alpha$ をできる限り小さくする方式 をとった，完全脆性破壊領域では $\alpha=15^{\circ}$ 僄移領域では $\alpha=30^{\circ} \sim 40^{\circ}$ 延性破壊が主なる領域では $\alpha=60^{\circ} \sim 70^{\circ}$ とした.

\section{4 破壊鞄性值の計算結果}

熱処理の異なる 5 種の試片 A， B， C，D，Eについて， 高温域に対しては Equivalent Energy 法を用いて $K^{*}$ $(T, \dot{K})$ を求め，低温域に対しては従来通りの方法で $K(T, \dot{K})$ を求めた. Fig. 7 (a) は静的 3 点曲げ試験結果

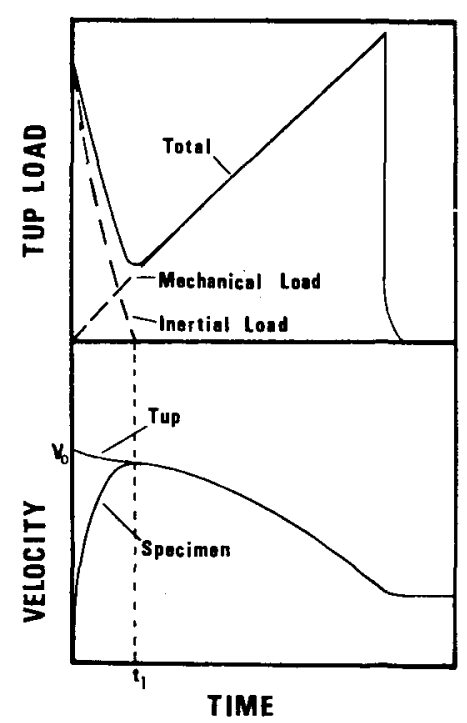

Fig. 5 Inertial load is generated when still specimen is suddenly accelerated by moving tup $^{3}$. 


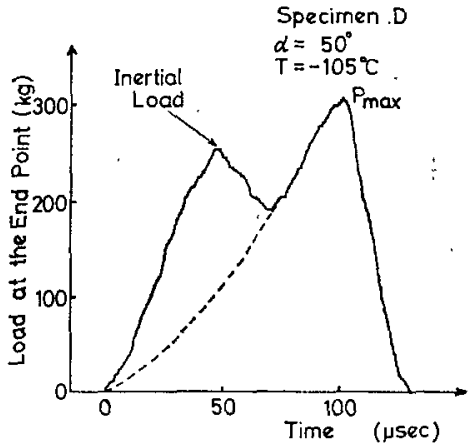

(a)

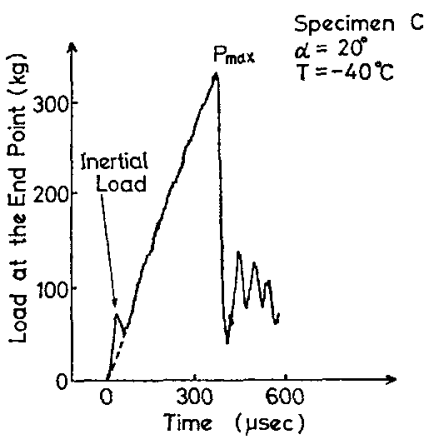

(b)

Fig. 6 Load-time curve (a) when tup speed is relatively high (Charpy arm angle $\alpha=50^{\circ}$ ) and the one (b) when tup speed is slower $\left(\alpha=20^{\circ}\right)$

であり，(b) は動的 3 点曲げ試験結果である。 $K$ のオー ダーは, 静的試験の場合が $10 \sim 10^{2} \mathrm{~kg}-\mathrm{mm}^{-3 / 2} / \mathrm{sec} の$ 筑囲であり，動的試験の場合は $10^{5} \sim 10^{6}$ の範团である. その差は 3 オーダー以上の違いがあった，動的，静的い ずれの場合においても，素材，HAZ 部相当の試片 $\mathrm{A}$, $\mathrm{B} ， \mathrm{D}$ は互いによく似た破罗敬性值の挙動を示し，ボン ド部相当の試片 C，E屯互いによく似た破壊僅性值の挙 動を示す. このように試片 $\mathrm{B}$ と D との間や, 試片 C と $\mathrm{E}$ の間においてはあまり差が見られない。よって SM 50 材においては入熱量の差に上る破壊䩲性値への影響は小 さいあのと思われる．一方静的，動的いずれの場合あ素 材, HAZ 部相当試片に比べ，ボンド部相当試片が低い 破買鞄性值を示した。な打破政欨性 $K(T, \dot{K})$ について 以後は試片 A， B，DをグループI と呼び，試片 C, E をグループII と呼ぶ.

\section{Equivalent Energy 法による破壊靭性 $\boldsymbol{K}^{*}(\boldsymbol{T}, \dot{\boldsymbol{K}})$ の有効性, 並びに計装化シャ ルピー試験法についての考察}

著者らの実験においては，Equivalent Energy 法を

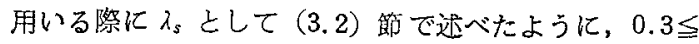

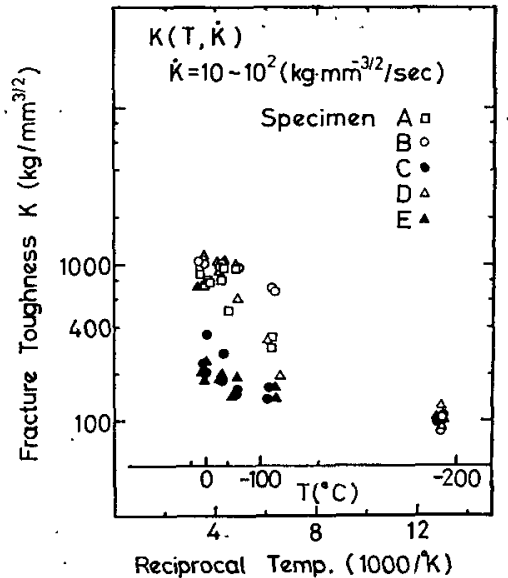

(a)

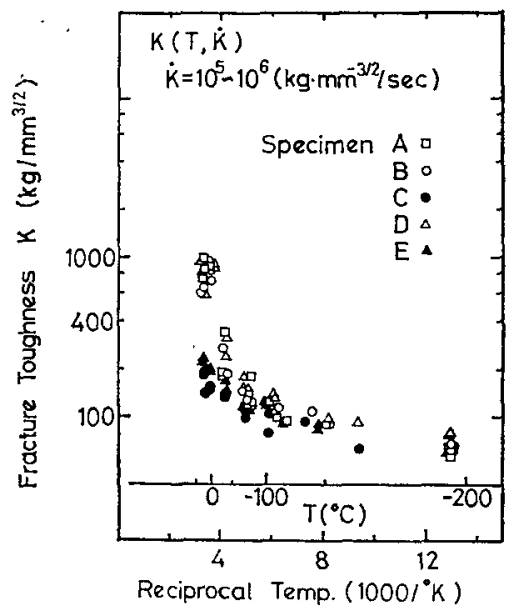

(b)

Fig. 7 Static fracture toughness values (A) and dynamic fracture toughness values (B)

$a / W \leqq 0.45$ の試片に対しては, 静的 3 点曲げ試験から 得られた式 $(3)$ を用いて $\lambda_{s}$ を決定した。このためこの 式(3)の妥当性を検討する. 弾性および small scale yielding の場合には $J=G$ であるので，近似として， $J$ 積分簡便法 $\left(J=\frac{2 A}{B(W-a)}\right)$ 亿よる破壊靱性值と $K^{*}$ $(T, \dot{K})$ は一致する. 乙れを延性破塄領域に延長し，そ の領域においても両者が一致するものと仮定する之，式 $(7,8)$ 办得ら机る. Fig. 8 亿式 $(7,8)$ の曲線を示 $E \lambda_{s} B=0.36 a(W-a)\{Y(a / W)\}^{2}$ (平面沈力) …...(7)

$E \lambda_{s} B=0.32 a(W-a)\{Y(a / W)\}^{2}$ (平面ひずみ) $\cdots(8)$

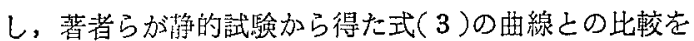
行なった。また図中には Saxton ら3の計算結果む示し てある.これは鋼のシャルピー型試片に乩いて，ローラ 一支持の 3 点曲げの場合にダグデール・モデルを適用し て, 平面ひずみの場合の FEM で求めた荷重点のコン 


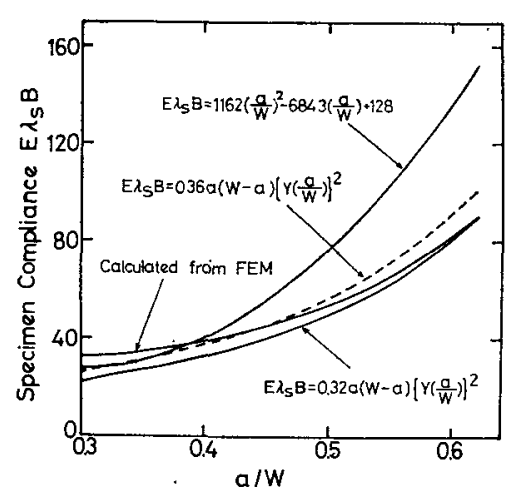

Fig. 8 Compliance $E \lambda_{s} B$ versus crack length when pre-cracked Charpy specimen is used

プライアンスである. 式 $(7,8)$ の両曲線は $a / W$ のほ ぼ全域にわたり FEM の計算結果とよく一致する。そ

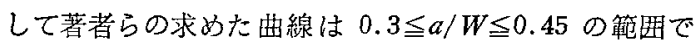
FEM の計算結果とよく一致するようであり，ての䇢囲 では式(3)を用いて試片コンプライアンスを求めてよい あのと思われる.

次に Equivalent Energy 法の計算を動的 3 点曲げ試 験に用いた場合の, 荷华一変位図の面積（エネルギ一） に関しての問題点述べる.

第一に（3.2）節で述べたでとく，本研究では試験機 のコンプライアンス $\lambda_{m}$ を実験データから逆算して間接 的に得たてとであり，精度的には問题がある.このため なんら汃の方法で $\lambda_{m}$ を直接測定し, Equivalent Energy 法に適用することが望ましい.

第二の問題点は荷重一時間曲線加ら荷重一変位曲線へ の変換の際に，タップ速度を $\sqrt{2 g h}$ で一定と仮定した ことである. 実際のタップ速度は前述の Fig. 5 亿示す でとく, 衝突後は次第に減速されるはずであり，【時間

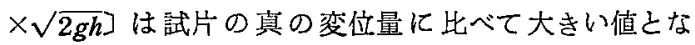
り，破壤までのエネルギーも真の值より大きいむのを計 算したことになる。

以上述べた試験機のコンプライアンス，タップ速度の 2 点に関する正確なデータが得られると, Equivalent Energy 法による $K^{*}(T, \dot{K})$ は，より信頼し得るもの となろう.

\section{2 計装化シャルピー試験についての考察}

チャージアンプの周波数特性に関しては式 ( 9 )が定義 される ${ }^{3)}$ との式を用いて，本実験に使用したチャージ

$$
T_{R}=0.35 / f_{0.9 d \mathrm{~B}}
$$

$T_{R}:$ アンプの応答時間

$f_{0.9 \mathrm{~dB}}:$ アンプ増幅度が10\%低下する周波数 アンプの 周波数特性から応答時間を求めると $T_{R}=2.9$ $\mu \sec$ が得られた. との応答時間は本実験における計装
化シャルピー試験で荷重一時間曲線を記録するには十分 小さい値である.

次に弾性波による測定誤差について考える.（3.3）節 で述べたでとく， $t_{f}>3 t$ であれば弹性波の影響は無視 される. そこで式( 5 )を用いて周期 $t$ を求めてみる. $T=-196^{\circ} \mathrm{C}, a=3.88 \mathrm{~mm}$ の試片の場合, $E \lambda_{s} B=39$, $C_{0}=6.1 \times 10^{6} \mathrm{~mm} / \mathrm{sec}$ であり $t=34.4 \mu \mathrm{sec}$ となり, $3 t$ $\doteqdot 100 \mu \mathrm{sec}$ である. 一方 $t_{f}$ は本実験ではもっとも短い 場合で $150 \mu \mathrm{sec}$ であったので $t_{f}>3 t$ は満たされてお り, 本実験に抢いては, 弾性波による誤差は無視され得 る.

\section{5. 破壊勒性の温度亡荷重速度への依存性の 考察}

\section{1 破壊靶性の温度依存性亡荷重速度依存性}

Fig. 7 のグループIの試片 A，B，D汇ついて，K $(T, \dot{K})-196^{\circ} \mathrm{C}$ と $K(T, \dot{K})-40^{\circ} \mathrm{C}$ 之を比較すると, 試片 A, B, D とあに静的な場合には $K(T, \dot{K})-40^{\circ} \mathrm{C}$ は $K$ $(T, \dot{K})_{-196^{\circ} \mathrm{C}}$ の約 9.5 倍であり，一方動的には，K

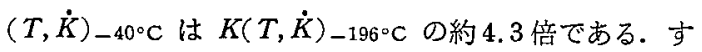
なわ荷重速度の低い場合の方が，荷重速度の高い場合 よりも温度依存性が大きく現れた。

Fig. 7 のグループIの試片 C， Eについては，静的，

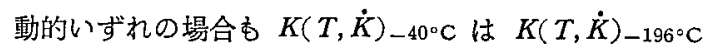
の約 2.4 倍であり, 荷重速度が異ってす温度依存性の差 は見られない。 またグループエとグループ温度依存 性を比較するを, 静的, 動的いずれの場合でも, グル一 プIの素材, HAZ 部相当試片の方がグループII のボン ド部相当試片よりも温度依存性が大きい，ただしその程 度は静的な場合の方が著しい。

Fig. 9 は室温付近を除いた各温度におけるグループ IとグループIIの荷重速度依存性を示したものである. 縱軸の $\Delta K(T, \dot{K})$ は同温度での静的, 動的破壊欨性の 差である. 液体窒㨞温度付近ではグループI とグループ III との間で荷重速度依存性の差はほ之んどなく, 高温側 に寄るにつれて，グループIに比べグループIの荷重速 度依存性は急激に大きくなっている。

\section{2 温度依存性, 荷重速度依存性の降伏強度によ る考察}

破壊靶性 $K(T, \dot{K})$ は, グループエとグループII とで は温度依存性, 荷重速度依存性が之もに異った傾向を示 す.これについて降伏強度 $\sigma_{y}$ をつのパラメータとし て定性的に考察を行なって見た， $\sigma_{y}$ ，の温度俵存性之荷 重速度依存性については数多くの研究がなされている。 Fig. 10 は $\sigma_{y}$ の温度低存性の曲線である.曲線は $\sigma_{v_{1} \text {. }}$ $=44 \mathrm{~kg} / \mathrm{mm}^{2}, \quad \sigma_{y 2 \cdot 0}=52 \mathrm{~kg} / \mathrm{mm}^{2}$ Ф 2 種類について, 


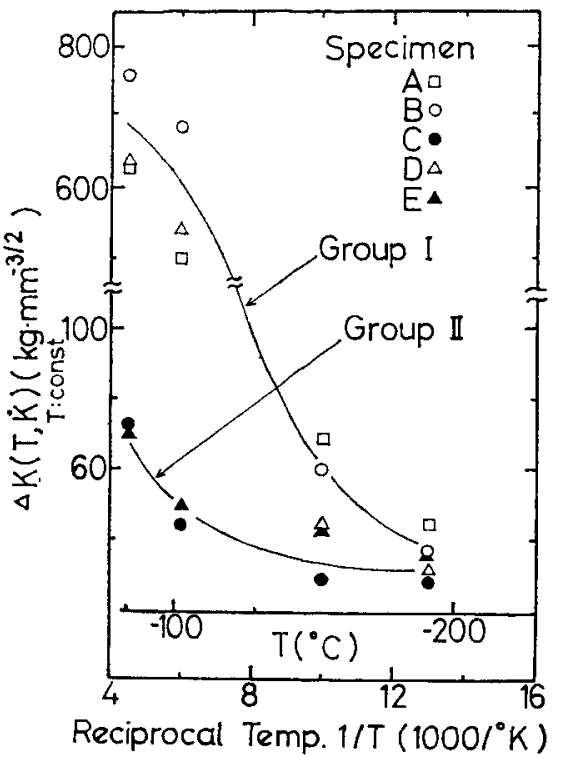

Fig. 9 Difference between static- and dynamic fracture toughness values: Group I shows stronger load-rate dependence when compared with Group II.

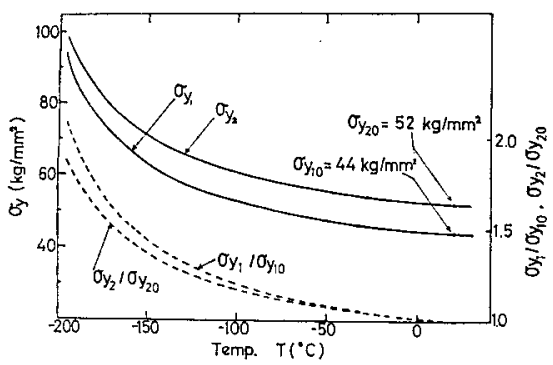

Fig. 10 Temperature dependence of yield points: The dependence is stronger for the steel whose yield point is greater than $50 \mathrm{~kg} /$ $\mathrm{mm}^{2}$, when compared with the one whose yield point is less than $50 \mathrm{~kg} / \mathrm{mm}^{2}$.

実験式(10)6) を用いて描いたすのである．また図中には 温度変化による降伏強度 $\sigma_{y_{1}} \sigma_{y_{2}}$ の変化の大きさを見 $\sigma_{y}=\sigma_{y 0} \exp \left\{\left(329.6-66.5 \ln \sigma_{y_{0}}\right)(1 / T-1 / 293)\right\}$

$\sigma_{y}:$ 温度 $T$ での降代強度

$\sigma_{y_{0}}:$ 室温での降伏強度

るために $\sigma_{y_{1}} / \sigma_{y_{1} \cdot 0}, \sigma_{y 2} / \sigma_{y 2 \cdot 0}$ の值を破線で示してあ る.図に見るように全温度範囲にわたり $\sigma_{y_{1}} / \sigma_{y_{1} \cdot 0}$ の値 の方が $\sigma_{y 2} / \sigma_{y 2 \cdot 0}$ の值を上回っている.つまり室温での 降伏強度が小さいほど, 降伏強度の温度依存性が大き い. 次に Fig. 11 は Shoemaker1〉らの求めた平面ひず み破壊勒性值 $K_{I_{c}} ， K_{I d}$ と $\sigma_{y}$ との対応関係を示した グラフである. $K_{I c} ， K_{I d}$ と $\sigma_{y}$ とには 1 対 1 の対応が

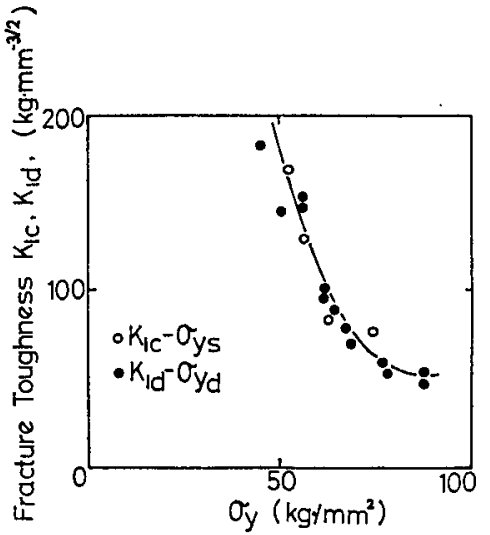

Fig. 11 One-to-one correlation between toughness value $\left(K_{I c}\right.$ or $\left.K_{I d}\right)$ and yield point (static or dynamic) ${ }^{1)}$

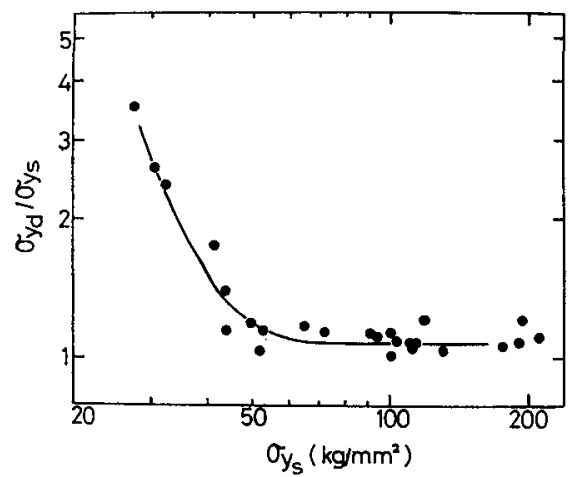

Fig. 12 Loading rate dependence of yield point $)^{7}$ )

あり，動的降伏点を考虑すれば，動的破壊鞄性值 $K_{I d}$, 之静的破壊欨性值 $K_{I_{c}}$ は同じすのとして扱うことがで きる. そして降伏強度の上昇に伴い， $K_{I_{c}} ， K_{I d}$ の值い 低下する．しかし降伏強度が非常に大きくなった場合に は $K_{I c} ， K_{I d}$ の低下の割合は小さくなる. Fig. 10, Fig. 11 を総合して次のてとがいえる. すなわち材料の 降伏强度 $\sigma_{y_{0}}$ は低温倒に行くにつれて上昇し，それに よって破壊靯性值 $K(T, \dot{K})$ は低下する. そしてその低 下の割合は室温降伏強度 $\sigma_{y_{0}}$ の小さいあのほど著しい。 本実験において，グループIは室温降伏強度 $\sigma_{y_{0}}<50 \mathrm{~kg}$ $/ \mathrm{mm}^{2}$ であり, グループ II は $\sigma_{y_{0}} \geqq 50 \mathrm{~kg} / \mathrm{mm}^{2}$ であっ たが，とのととによって両グループの破壊姕性值の温度 依存性に差を生じたむの之思われる。

さて次に荷重速度依存性について述べる. Fig. $12^{7}$ は動的荷重が降伏強度に対して及代す影響を示したもの である. 縦韩で， $\sigma_{y_{d}}$ は動的荷重下での降伏点， $\sigma_{y_{s}}$ は 静的荷重下での除伏点を示す． $\sigma_{y_{s}}$ が大きいほど, 動荷 重による降伏強度の上昇は小さく， $\sigma_{y_{s}}>50 \mathrm{~kg} / \mathrm{mm}^{2}$ で は $\sigma_{y_{d}} / \sigma_{y_{s}}$ はほぼ一定值をとるようである. Fig. 11, 
Fig. 12 を総合すると $\sigma_{y_{s}}<50 \mathrm{~kg} / \mathrm{mm}^{2}$ の材料では動荷 重を与える之降伏強度が大きく上异し，そのため破壊鞄 性 $K(T, \dot{K})$ が低下する，そのときそのの低下の割合は $\sigma_{y_{s}}$ の小さいあのほど著しい，また $\sigma_{y_{s}} \geqq 50 \mathrm{~kg} / \mathrm{mm}^{2}$ の 材料では，動荷重による降伏強度の上昇はわずかであ り，そのため破壊鞄性 $K(T, \dot{K})$ の低下は少い。また $\sigma_{y_{s}}$ がひじょうに大きくなってあその低下の勾配はほと んぞ変化しない．とのように本実験における両グループ の荷重速度依存性の差む, 上記の降伏強度の挙動とその 破罗䩓性值への勃果加ら説明されるすのと思われる。従 来溶接構造物においては，ボンド部の㗆性がとくに悪 く，ボンドに最大の注意を払うという考元が一般的であ ったししかし少くとも SM50 材については，高荷重速 度を受ける可能性を持つ構造物においては，素材， HAZ にあ同様の考虑がなされるべきであろうと思われる.

\section{6. 結論}

SM50 材溶接再現熱サイクル材を用いて，溶接部破壊 靯性を定量的に求め, その荷重速度依存性, 温度依存性 を明らかにし，同時に動的破壊勒性值の簡便な測定法之 しての計䒾化シャルピ一試験法の有効性を検討した。

(1) SM 50 材の溶接部における破壊靯性は, ボンド が HAZ 素材に比べて劣る. しかし入熱量の差による 違いは小さい.

（2） SM 50 材の破買靱性は素材，再現熱サイクル材 ともに室温付近を除く全温度範囲で荷重速度の影響を受 け，動的破壊勒性は静的破壊勒性より屯劣る.

（3） SM 50 材の破壊勒性の荷重速度依存性, 温度依 存性は素材, HAZ 相当試片において著しく,ボンド相 当試片では少い，とのため高荷重速度を受ける場合に は，溶接ボンド部とともに $\mathrm{HAZ}$ 部にも注意を払うべ
きである.

（4）本研究において動的 3 点曲げ試験に用いた荷重 湘定系（荷重センサーーチャージ・アンプー高速現象デ

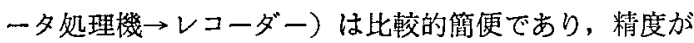
高い。またシャルピー試験機のハンマーの持ち上げ角を 小さくすることで, 弾性波, inertial load の影響をほ とんどなくすととが可能であり，との計装化シャルピー 試験法は動的破壤靬性測定法として有効なものと思われ ろ.

（5） Equivalent Energy 法はむし試片のコンプラ イアンスおよび使用試験機のそれが算出ないしは実測で きる場合，脆性・延性遷移域での破壞脆性值算定の便法 となりうる.

本研劣の遂行にあたり, Effect Technology 社のプリ ・クラッカーを使用したが，乙の装置を使用させてくだ さった神戸製鋼所・中央研究所に厚くお礼申しあげま す.また同研究所の小出憲司氏との有意義な討議を感謝 いたします。

\section{参考 文 献}

1) A.K. Shoemaker and S.T.Rolfe : Static and Dynamic Low-Temperature $K_{I c}$ Behavior of Steels, J. bas. Engng Trans. ASME, 91 (1969), No. 3, p. 512

2) W.B Bedesem in ASME Publication 68-PVP-4 (1968)

3) Instrumented Impact Testing, ASTM STP 563 (1974)

4) F.J. Witt, Proceedings, Fourth National Symposium Fracture Mechancics, Pittsburgh, Pa., Aug. (1970), p. 24

5) D. R. Irelnd, Private Communication

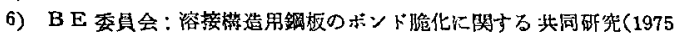
-7)

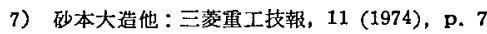

\title{
アーク溶接時に発生するヒュームの測定に関する研究（第 1 報）*
}

\author{
西田隆法**宮本 栄**三上 博****
}

\author{
Study on the Measuring of Fume Density Produced \\ by Arc Welding (1st Report)*
}

by Takanori Nishida**, Sakae Miyamoto** and Hiroshi Mikami***

It is said that fume produced during arc welding is harmful for human body, but there has been no simple and easy method to measure fume density in welding shop.

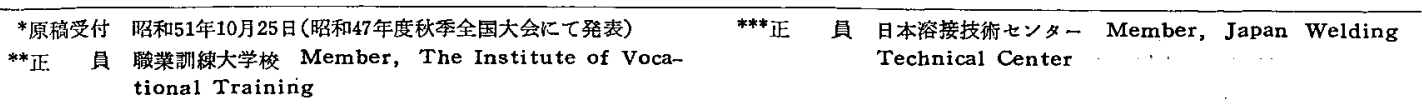

